Ann. rheum. Dis. (1962), 21, 51.

\title{
SERUM AND SYNOVIAL FLUID PROTEINS IN ARTHRITIS
}

\author{
BY \\ MATTHEW WILKINSON AND BRIAN S. JONES \\ From the Clinical Research Department, Charing Cross Hospital, and the Department of Pathology, \\ St. Bartholomew's Hospital, London
}

Synovial fluid is generally considered to be a dialysate of plasma to which mucin has been added during its passage through the synovial membrane (Ropes and Bauer, 1953). The proteins of the serum and synovial fluid have been shown to be qualitatively identical (Schmid and MacNair, 1956) and the concentrations of the various proteins in synovial fluid probably depend upon the following factors:

(1) The molecular weights of the various protein fractions; the smaller albumin molecules achieving relatively higher concentrations in the normal synovial fluid than the large globulin molecules (Decker, McKenzie, McGuckin, and Slocumb, 1959).

(2) The permeability of the synovial membrane; the inflamed membrane is more permeable and allows through more protein and especially more of the larger globulins (Decker and others, 1959).

(3) The rate of absorption of synovial fluid from the joints; there is some evidence that the rate of egress from the synovial fluid is particularly slow for large globulin molecules (Bauer, Short, and Bennett, 1933); also, in rheumatoid subjects, the absorption of proteins is more rapid from arthritic than from non-involved joints (Ahlström, Gedda, and Hedberg, 1956).

While there is no good evidence for the direct secretion of protein into the synovial fluid, the possibility is by no means excluded (Nettelbladt and Sundblad, 1961).

In the present study the electrophoretic patterns of serum and synovial fluid proteins in various diseases have been analysed, partly for their value in diagnosis, but also to shed further light on the formation of synovial fluid.

\section{Material and Methods}

Electrophoretic studies were made on serum and synovial fluid taken simultaneously. The synovial fluid was taken from one or both knee joints of the patients listed in Table I.

TABLE 1

PATIENTS STUDIED AND SPECIMENS ANALYSED

\begin{tabular}{|c|c|c|c|c|c|}
\hline Disease & & $\begin{array}{c}\text { No. } \\
\text { of } \\
\text { Patients }\end{array}$ & $\begin{array}{c}\text { No. } \\
\text { of } \\
\text { Sera }\end{array}$ & & $\begin{array}{c}\text { No. of } \\
\text { Synovial } \\
\text { Fluids }\end{array}$ \\
\hline $\begin{array}{l}\text { Osteo-arthritis } \quad \ldots \\
\text { Traumatic Synovitis } \\
\text { Rheumatoid Arthritis } \quad \ldots \\
\text { Rheumatic Fever } \\
\text { Myeloma and Osteo-arthritis } \\
\text { Sarcoidosis } \\
\text { Ankylosing Spondylitis }\end{array}$ & $\begin{array}{l}\cdots \\
\cdots \\
\cdots \\
\cdots \\
\cdots \\
\cdots\end{array}$ & $\begin{array}{r}19 \\
6 \\
20 \\
2 \\
1 \\
1 \\
1\end{array}$ & $\begin{array}{r}20 \\
6 \\
31 \\
2 \\
1 \\
1 \\
1\end{array}$ & & $\begin{array}{r}21 \\
6 \\
38 \\
3 \\
2 \\
1 \\
1\end{array}$ \\
\hline
\end{tabular}

The diagnoses were established on a combination of clinical and radiological grounds, together with the results of latex-agglutination tests, using the method of Singer and Plotz (1958), slightly modified in that the tubes were left at room temperature for $18 \mathrm{hrs}$ and not refrigerated. The final result was then read without centrifuging and the degree of flocculation was graded from 0 , representing no flocculation, to ++++ , representing complete precipitation of the latex particles.

Synovial needle biopsies were taken at the time of aspiration from eight osteo-arthritic joints, thirteen rheumatoid joints, and from the knee joint of one patient with concurrent osteo-arthritis and myelomatosis.

Using the revised criteria (1958) of the American Rheumatism Association (Ropes, Bennett, Cobb, Jacox, and Jessar, 1959), fifteen of the patients with rheumatoid arthritis would be described as classical and five as definite cases.

Total protein estimations were made on serum and synovial fluid using a biuret method.

Electrophoresis was performed on untreated serum, but synovial fluid was first incubated for $2 \mathrm{hrs}$ at $37^{\circ} \mathrm{C}$. with testicular hyaluronidase (400 i.u./ml. synovial fluid) to reduce the viscosity, and was then dialysed against 35 per cent. polyvinylpyrrolidine to produce a protein content of 5 to $8 \mathrm{~g}$. per cent. $0.02 \mathrm{ml}$. of serum or treated synovial fluid was applied to a $7 \cdot 5-\mathrm{cm}$. width of Whatman No. 1 paper and the separation was performed in a horizontal tank (Shandon) using Veronal 
buffer (pH 8.6, ionic strength $0 \cdot 05$ ), with the current and duration of the electrophoresis arranged to give a strip length of 10 to $12 \mathrm{~cm}$. The strips were dried for $15 \mathrm{~min}$. at $100^{\circ} \mathrm{C}$., stained for $10 \mathrm{~min}$. with Light Green (Gurr), and repeatedly rinsed in 2 per cent. acetic acid until a white background was obtained. After drying, the strips were oiled and scanned in an Evans electrodensitometer, and absolute values for each protein fraction were calculated from the total protein value and the results of planimetry on the electrophoretic curves. No correction was made for differences in staining of the various protein fractions.

Students " $t$ " test was used for all statistical comparisons.

\section{Results}

The mean values (in $\mathrm{g}$. per cent.) of the various serum and synovial fluid protein fractions for each disease group are shown in Table II.

Because of the small volume of synovial fluid in a normal joint it was impossible to make comparisons with a normal group and, since the serum (though not the synovial fluid) is said to be normal in osteo-arthritis (Jencks, Smith, and Durrum, 1956), this group has been used as a baseline for comparisons.

\section{Osteo-arthritis}

Despite the alleged normality of the serum proteins in osteo-arthritis, these cases do not necessarily constitute a homogeneous group. When sub므. divided according to the duration of the effusion? (Table III, opposite), cases with an effusion for les $\overrightarrow{\vec{s}}$ than 2 weeks showed significantly higher serum alpha $_{2}$ globulin and synovial fluid total protein anf gamma globulin levels than did cases with long standing effusions. In fact, the figures for cases with recent effusions were remarkably similar to those fof cases of traumatic synovitis. The high serum alpha@ globulin is a non-specific finding in almost and inflammatory condition, and the higher synoviat fluid proteins are probably a reflection of increased permeability due perhaps to a more acute inflame mation in the early stages of an osteo-arthritie effusion.

When the figures for individual cases are con:sidered, the striking finding was the low synoviat fluid gamma globulin levels. Only three of the 21 synovial fluids contained more than $1 \mathrm{~g}$. per cent. of gamma globulin.

\section{Traumatic Synovitis}

These patients showed significantly higher serunis alpha $_{2}$ and gamma globulin levels but, although the synovial fluid protein fractions were consistently higher than those for osteo-arthritis-suggesting rather higher permeability, the differences were not statistically significant.

TABLE II

MEAN VALUES FOR THE VARIOUS SERUM AND SYNOVIAL FLUID PROTEIN FRACTIONS IN DIFFERENT JOINT DISEASES

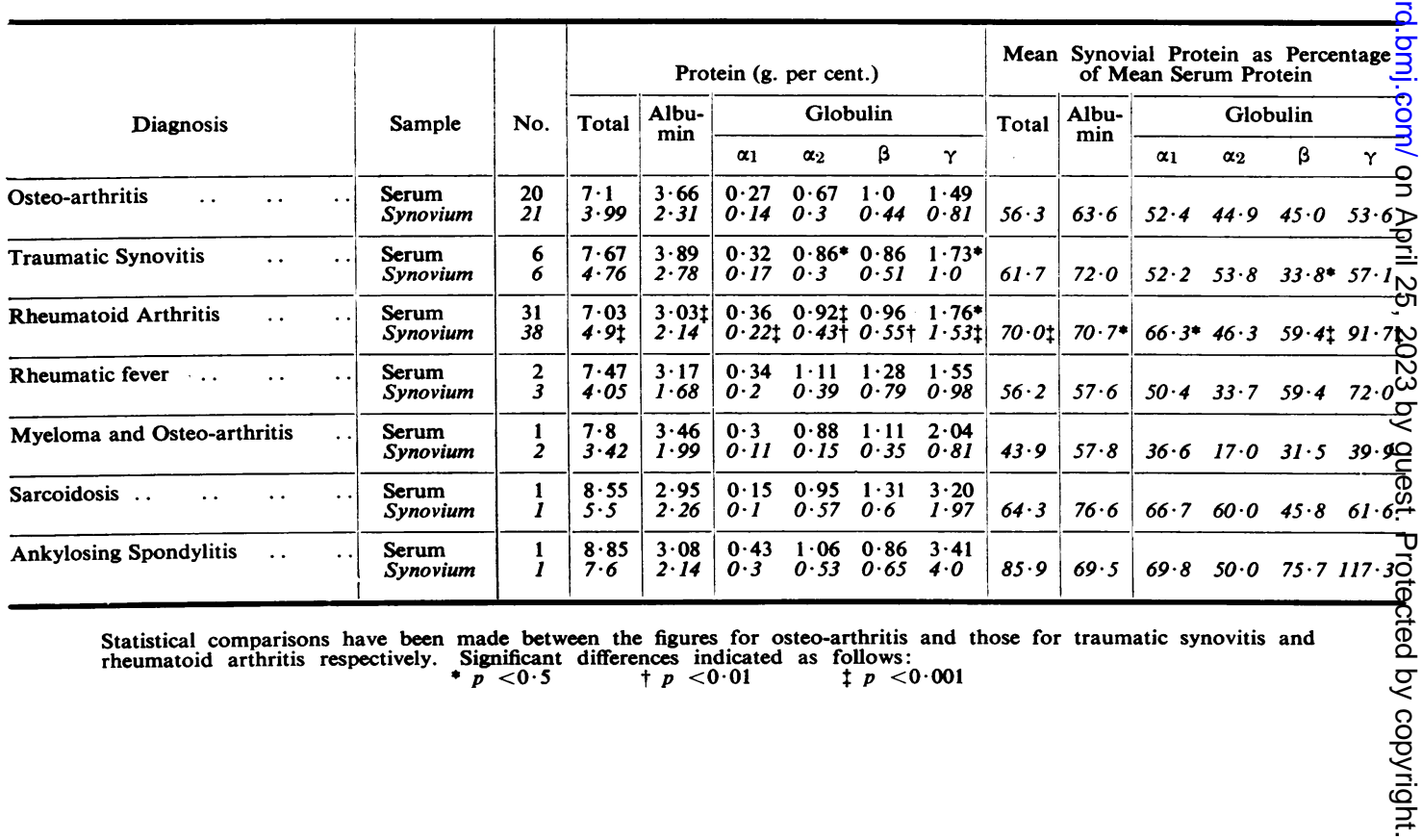


TABLE III

SERUM AND SYNOVIAL FLUID PROTEINS IN OSTEO-ARTHRITIS CLASSIFIED BY DURATION OF DISEASE

\begin{tabular}{|c|c|c|c|c|c|c|c|c|c|c|c|c|c|c|c|c|c|}
\hline \multirow{3}{*}{\multicolumn{3}{|c|}{$\begin{array}{l}\text { Duration of Diseases } \\
\text { (wks) }\end{array}$}} & & \multirow{3}{*}{ Sample } & \multirow{3}{*}{$\begin{array}{l}\text { No. of } \\
\text { Samples }\end{array}$} & \multicolumn{6}{|c|}{ Protein (g. per cent.) } & \multicolumn{6}{|c|}{$\begin{array}{l}\text { Mean Synovial Protein as Percentage } \\
\text { of Mean Serum Protein }\end{array}$} \\
\hline & & & & & & \multirow{2}{*}{ Total } & \multirow{2}{*}{$\begin{array}{c}\text { Albu- } \\
\text { min }\end{array}$} & \multicolumn{4}{|c|}{ Globulin } & \multirow{2}{*}{ Total } & \multirow{2}{*}{$\begin{array}{c}\text { Albu- } \\
\text { min }\end{array}$} & \multicolumn{4}{|c|}{ Globulin } \\
\hline & & & & & & & & $\alpha_{1}$ & $\alpha_{2}$ & $\beta$ & $\gamma$ & & & $\alpha_{1}$ & $\alpha_{2}$ & $\beta$ & $\gamma$ \\
\hline$<3$ & $\cdots$ & $\cdots$ & $\cdots$ & $\underset{\text { Synovium }}{\text { Serum }}$ & 4 & $\begin{array}{l}7 \cdot 55 \\
4 \cdot 81\end{array}$ & $\begin{array}{l}3 \cdot 75 \\
2 \cdot 57\end{array}$ & $\begin{array}{l}0 \cdot 27 \\
0 \cdot 16\end{array}$ & $\begin{array}{l}0 \cdot 84 \\
0 \cdot 37\end{array}$ & $\begin{array}{l}1 \cdot 03 \\
0 \cdot 51\end{array}$ & $\begin{array}{l}1 \cdot 65 \\
1 \cdot 19\end{array}$ & $63 \cdot 6$ & $69 \cdot 3$ & $58 \cdot 2$ & $45 \cdot 4$ & $49 \cdot 9$ & $72 \cdot 9$ \\
\hline $2-13$ & $\cdots$ & $\cdots$ & $\cdots$ & $\begin{array}{l}\text { Serum } \\
\text { Synovium }\end{array}$ & $\begin{array}{l}7 \\
7\end{array}$ & $\begin{array}{l}6 \cdot 85 \\
3 \cdot 54^{*}\end{array}$ & $\begin{array}{l}3 \cdot 63 \\
2 \cdot 15\end{array}$ & $\begin{array}{l}0 \cdot 24 \\
0 \cdot 11\end{array}$ & $\begin{array}{l}0 \cdot 65^{*} \\
0 \cdot 25\end{array}$ & $\begin{array}{l}0 \cdot 86^{*} \\
0 \cdot 36^{*}\end{array}$ & $\begin{array}{l}1 \cdot 46 \\
0 \cdot 67 *\end{array}$ & $51 \cdot 3$ & $58 \cdot 5$ & $46 \cdot 5$ & $37 \cdot 2$ & $42 \cdot 3$ & $45 \cdot 6$ \\
\hline$>13$ & $\cdots$ & $\cdots$ & $\ldots$ & $\begin{array}{l}\text { Serum } \\
\text { Synovium }\end{array}$ & $\begin{array}{r}9 \\
10\end{array}$ & $\begin{array}{l}7.09 \\
3.98\end{array}$ & $\begin{array}{l}3 \cdot 64 \\
2 \cdot 31\end{array}$ & $\begin{array}{l}0.27 \\
0.15\end{array}$ & $\begin{array}{l}0 \cdot 61^{*} \\
0 \cdot 31\end{array}$ & $\begin{array}{l}1 \cdot 1 \\
0 \cdot 47\end{array}$ & $\begin{array}{l}1 \cdot 45 \\
0 \cdot 75 *\end{array}$ & $57 \cdot 3$ & 65.0 & $54 \cdot 3$ & $50 \cdot 1$ & $45 \cdot 0$ & $52 \cdot 7$ \\
\hline
\end{tabular}

Statistical comparisons have been made against the cases of less than 2 weeks' duration. Significant differences indicated as in Table II.

\section{Rheumatoid Arthritis}

Compared with the osteo-arthritic subjects, these patients showed significantly lower serum albumin and higher serum alpha ${ }_{2}$ and gamma globulin levels, while in the synovial fluid, the total protein and all globulin levels were significantly higher. As might be expected, the synovial fluid/serum ratios suggested greater penetration of almost all of the protein fractions into the synovial fluid.

When the rheumatoid cases are subdivided according to duration of disease, the following trends emerge in both serum and synovial fluid (Table IV). With increasing duration the initially low total protein and albumin levels rose towards normal, the high alpha 2 globulin fell towards normal, and the near normal gamma globulin rose markedly. These changes were much more marked and reached statistical significance only in the synovial fluid.

The synovial fluid/serum ratios suggest increasing permeability of the synovial membrane with increasing duration of disease; this is presumably a reflection of the increasing vascularity of the synovial membrane. The permeability for gamma globulin in rheumatoid arthritis seemed exceptionally high and exceeded the permeability for albumin by a considerable margin even in early cases.

Since few early cases, but more than half of the long-duration cases, were receiving steroid therapy, it seemed possible that some of these protein changes were the result of treatment. However, this can be discounted since separate analyses of steroid-treated and untreated cases showed exactly the same changing protein patterns with increasing duration of disease.

Inspection of the individual figures revealed that all except two of the 38 rheumatoid synovial fluids contained more than $1 \mathrm{~g}$. per cent. gamma globulin, and these were both from patients in whom the disease was of very recent onset.

A study of the thirteen rheumatoid synovial

TABLE IV

SERUM AND SYNOVIAL FLUID PROTEINS IN RHEUMATOID ARTHRITIS CLASSIFIED BY DURATION OF DISEASE

\begin{tabular}{|c|c|c|c|c|c|c|c|c|c|c|c|c|c|c|c|c|c|}
\hline \multirow{3}{*}{\multicolumn{3}{|c|}{$\underset{(y r s)}{\text { Duration of Disease }}$}} & & \multirow{3}{*}{ Sample } & \multirow{3}{*}{$\begin{array}{l}\text { No. of } \\
\text { Samples }\end{array}$} & \multicolumn{6}{|c|}{ Protein (g. per cent.) } & \multicolumn{6}{|c|}{$\begin{array}{c}\text { Mean Synovial Protein as Percentage } \\
\text { of Mean Serum Protein }\end{array}$} \\
\hline & & & & & & \multirow[t]{2}{*}{ Total } & \multirow{2}{*}{$\begin{array}{c}\text { Albu- } \\
\text { min }\end{array}$} & \multicolumn{4}{|c|}{ Globulin } & \multirow[t]{2}{*}{ Total } & \multirow{2}{*}{$\begin{array}{c}\text { Albu- } \\
\text { min }\end{array}$} & \multicolumn{4}{|c|}{ Globulin } \\
\hline & & & & & & & & $\alpha_{1}$ & $\alpha_{2}$ & $\beta$ & $\gamma$ & & & $\alpha_{1}$ & $\alpha_{2}$ & $\beta$ & $\gamma$ \\
\hline$<1$ & . & $\cdots$ & . & $\begin{array}{l}\text { Serum } \\
\text { Synovium }\end{array}$ & 5 & $\begin{array}{l}6 \cdot 39 \\
4 \cdot 13\end{array}$ & $\begin{array}{l}2 \cdot 68 \\
1 \cdot 73\end{array}$ & $\begin{array}{l}0 \cdot 39 \\
0 \cdot 25\end{array}$ & $\begin{array}{l}1 \cdot 02 \\
0 \cdot 55\end{array}$ & $\begin{array}{l}0.94 \\
0.51\end{array}$ & $\begin{array}{l}1 \cdot 34 \\
1 \cdot 08\end{array}$ & $63 \cdot 1$ & $62 \cdot 1$ & $64 \cdot 6$ & $53 \cdot 3$ & $55 \cdot 0$ & $81 \cdot 8$ \\
\hline $1-5$ & $\cdots$ & $\cdots$ & $\cdots$ & $\begin{array}{l}\text { Serum } \\
\text { Synovium }\end{array}$ & 10 & $\begin{array}{l}7 \cdot 37^{*} \\
4 \cdot 99+\end{array}$ & $\begin{array}{l}3 \cdot 18 \\
2 \cdot 21 *\end{array}$ & $\begin{array}{l}0 \cdot 38 \\
0 \cdot 22\end{array}$ & $\begin{array}{l}0 \cdot 94 \\
0.44\end{array}$ & $\begin{array}{l}1 \cdot 07 \\
0 \cdot 6^{*}\end{array}$ & $\begin{array}{l}1 \cdot 81 * \\
1 \cdot 51+\end{array}$ & $67 \cdot 7$ & $70 \cdot 8$ & $58 \cdot 3$ & $50 \cdot 2$ & $56 \cdot 0$ & $85 \cdot 2$ \\
\hline$>5$ & $\cdots$ & $\ldots$ & $\cdots$ & $\begin{array}{l}\text { Serum } \\
\text { Synovium }\end{array}$ & $\begin{array}{l}16 \\
21\end{array}$ & $\begin{array}{l}7 \cdot 02 \\
5 \cdot 02+\end{array}$ & $\begin{array}{l}3 \cdot 05 \\
2 \cdot 21+\end{array}$ & $\begin{array}{l}0 \cdot 33 \\
0 \cdot 21\end{array}$ & $\begin{array}{l}0 \cdot 88 \\
0.39 *\end{array}$ & $\begin{array}{l}0.9 \\
0.54\end{array}$ & $\begin{array}{l}1 \cdot 86 \\
1 \cdot 67 *\end{array}$ & $73 \cdot 2^{*}$ & $73 \cdot 1 *$ & $71 \cdot 0$ & $44 \cdot 7$ & $62 \cdot 7$ & $93 \cdot 2$ \\
\hline
\end{tabular}




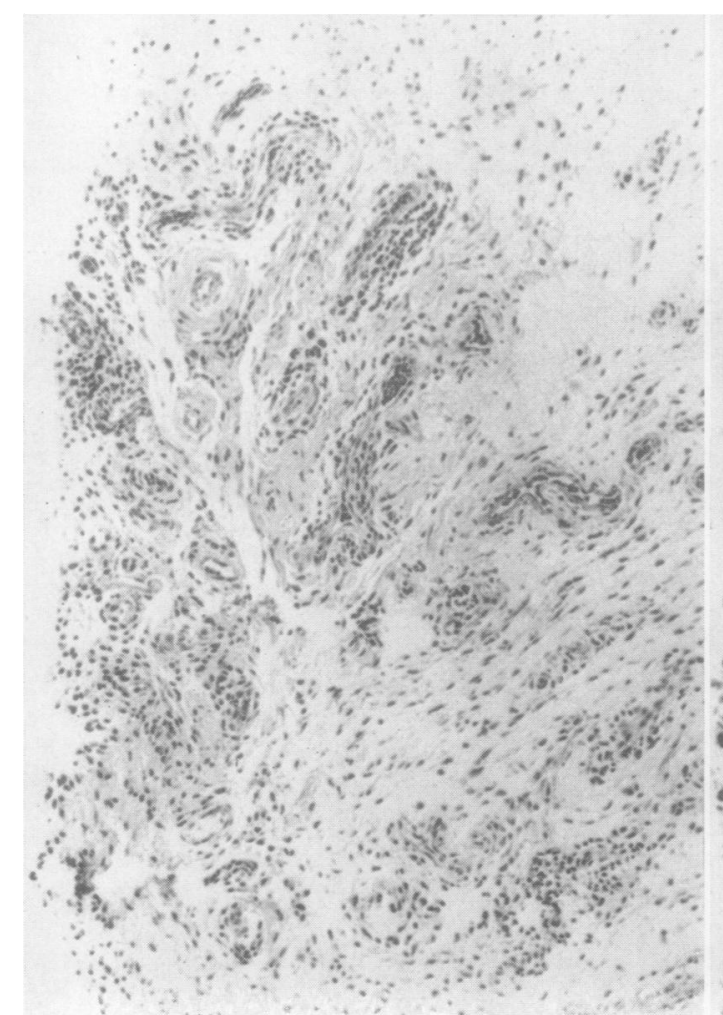

(a)

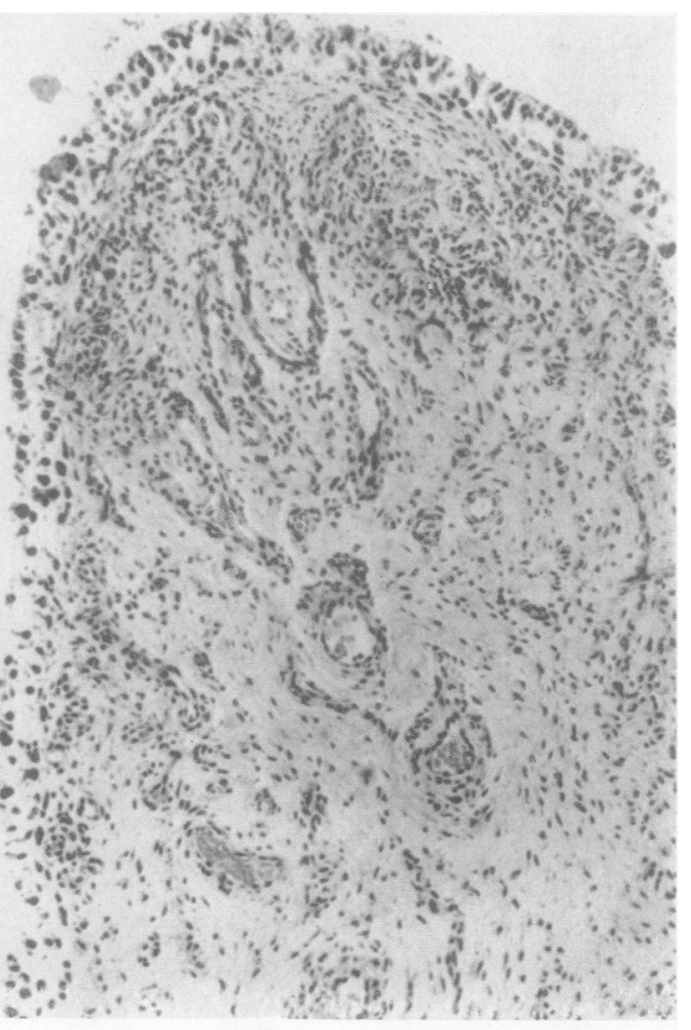

(b)

Figure.-Synovial biopsies from four rheumatoid arthritic patients.

The gamma globulin levels (g. per cent) of fluids from these joints were $(a) 1 \cdot 08,(b) 1 \cdot 48,(c) 1 \cdot 98,(d) 3 \cdot 78$.

biopsies suggested a correlation between intensity of lymphocytic infiltration and synovial fluid gamma globulin levels (FIGURE).

One particular gamma globulin that can be studied in serum and synovial fluid is the rheumatoid factor. Latex-fixation tests were therefore performed on at least one serum and one synovial fluid specimen from each rheumatoid patient.

Twelve of the twenty patients with rheumatoid arthritis gave a positive serum latex-fixation test. Generally, the degree of agglutination of the latex particles was less in the synovial fluid than in the serum. However, in three of these cases, the synovial fluid gave a stronger reaction than the serum, and in a further case the synovial fluid was positive whilst the serum was negative. There appeared to be no correlation between the amount of gamma globulin present in these fluids and the result of the latex-fixation test, presumably because the rheumatoid factor comprises such a small proportion c 1 the total gamma globulin.

Control tests on fifteen non-rheumatoid sera and synovial fluids were all negative, except for weak positive reactions on the serum from one and on the synovial fluid from another osteo-arthritic patient. These were considered to be false positive reactions.

In view of these results it appears worthwhile to perform the latex-fixation test on both serum $\frac{3}{3}$ and synovial fluid in diagnostically difficult cases presenting with joint effusions.

\section{Other Diseases}

Few worth-while deductions can be made from $N$ so few cases, though it is of interest that the patient $N$ with ankylosing spondylitis and a long-standing $N$ knee-joint effusion showed serum and synovial $\omega$ fluid protein patterns of the rheumatoid type. The patients with sarcoidosis and myelomatosis $\stackrel{\circ}{=}$

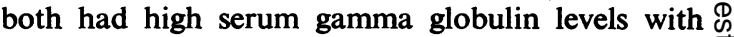
only moderate penetration into the synovial fluid. As might be expected, this was particularly so for ${ }^{-}$ the myeloma globulin, though sufficient did reach $\vec{D}$ the synovial fluid to produce a good gamma globulin $\frac{\rho}{\mathbb{D}}$ "peak". This gamma globulin was unlikely to $\varrho$ 


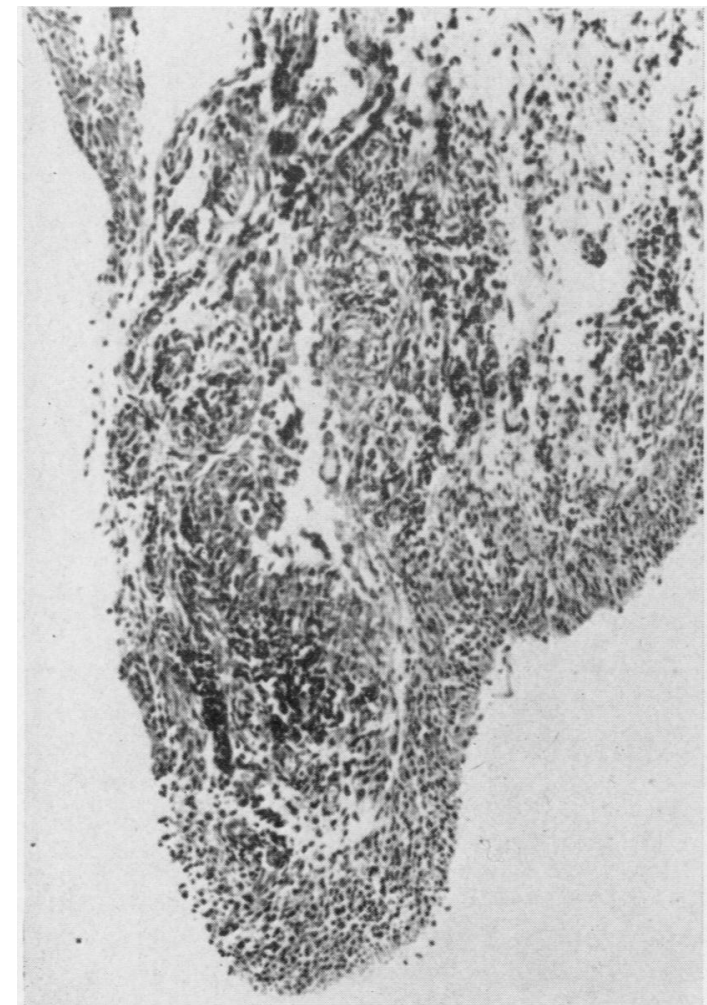

(c)

have been produced locally in the synovium since a synovial biopsy showed no significant infiltration with plasma cells.

\section{Discussion}

As a diagnostic aid, the synovial fluid protein electrophoretic pattern is rarely more helpful than that of the serum. Indeed, in most diseases, the two are remarkably alike, as can be seen from Table $\mathrm{V}$ (overleaf), where the various protein fractions are expressed as a percentage of the total serum or synovial fluid proteins.

Even an estimation of the absolute protein values provides relatively little return for the labour involved. From a diagnostic point of view, one of the most useful observations was the synovial fluid gamma globulin, which was below $1 \mathrm{~g}$. per cent. in all except three of the 21 osteo-arthritic fluids and above this level in all except two of the 38 rheumatoid fluids. The synovial fluid gamma globulin was variable in the other arthritides studied. Even more helpful was the synovial fluid/serum gamma globulin ratio, which was below 70 per cent. in all except three of the 21 osteo-arthritic effusions

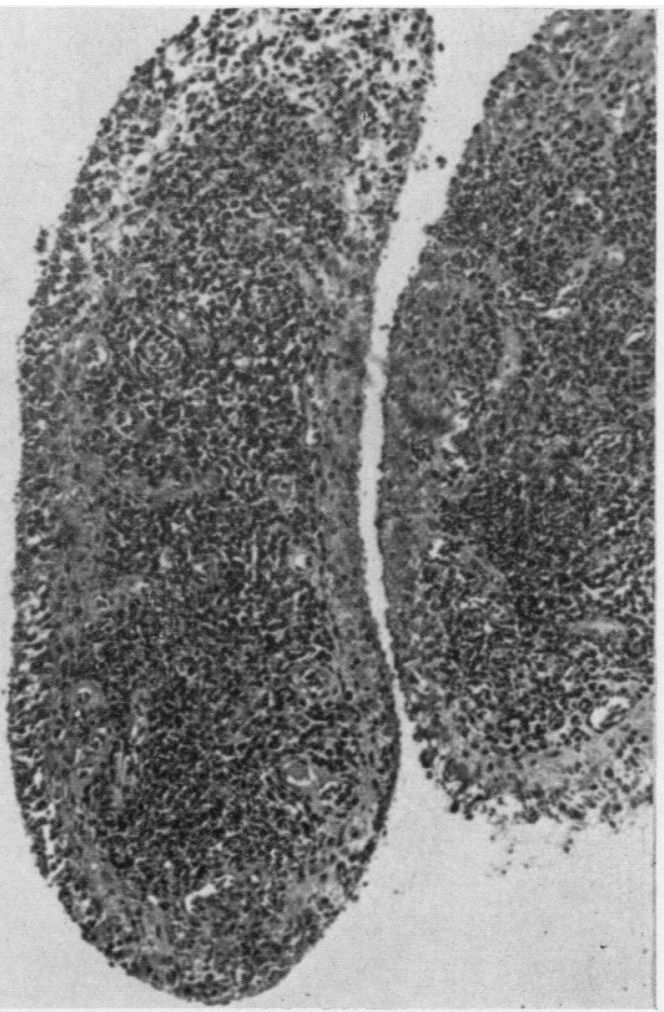

(d)

and in all six of the traumatic effusions, and above 70 per cent. in all except five of the 38 rheumatoid effusions. If this information could be obtained more simply by using a flocculation test, it might provide a useful diagnostic tool for the diagnosis of arthritis.

Consideration of these findings in terms of pathological physiology is hampered by the lack of observation on normal synovial fluid. The small volume and low protein content of normal synovial fluid made it impossible to concentrate the fluid up to a protein content similar to that of normal serum. This is a necessary preliminary step if the electrophoretic analyses of serum and synovial fluid are to be comparable.

Nevertheless, if one studies the synovial fluid/ serum total protein ratios in Table II, the increasing ratios found in osteo-arthritis, traumatic synovitis, and rheumatoid arthritis might be judged to indicate increasing synovial permeability due to increasing grades of inflammation. This would not, however, explain the exceptionally high synovial fluid/serum gamma globulin ratio in rheumatoid arthritis, which is so much higher than that for any other protein 
TABLE V

MEAN SERUM AND SYNOVIAL FLUID PROTEINS (g. per cent.) IN VARIOUS DISEASES PROTEIN FRACTIONS EXPRESSED AS PERCENTAGE OF TOTAL SERUM OR SYNOVIAL FLUID PROTEIN

\begin{tabular}{|c|c|c|c|c|c|c|c|c|c|c|c|}
\hline \multirow{2}{*}{\multicolumn{4}{|c|}{ Diagnosis }} & \multirow{3}{*}{$\begin{array}{l}\text { Sample } \\
\text { Serum } \\
\text { Synovium }\end{array}$} & \multirow{3}{*}{$\begin{array}{c}\begin{array}{c}\text { No. of } \\
\text { Samples }\end{array} \\
20 \\
21\end{array}$} & \multirow{3}{*}{$\begin{array}{l}\begin{array}{c}\text { Total } \\
\text { Protein }\end{array} \\
\begin{array}{l}7 \cdot 1 \\
3 \cdot 99\end{array}\end{array}$} & \multirow{3}{*}{$\begin{array}{c}\text { Albumin } \\
51 \cdot 5 \\
58 \cdot 0\end{array}$} & \multicolumn{4}{|c|}{ Globulin } \\
\hline & & & & & & & & \multirow{2}{*}{$\begin{array}{c}\alpha_{1} \\
3 \cdot 8 \\
3 \cdot 5\end{array}$} & \multirow{2}{*}{$\begin{array}{l}\alpha_{2} \\
9 \cdot 4 \\
7 \cdot 5\end{array}$} & \multirow{2}{*}{ 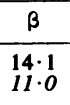 } & \multirow{2}{*}{$\frac{\gamma}{21} \frac{\gamma}{20 \cdot 3}$} \\
\hline Osteo-arthritis & . & . & $\cdots$ & & & & & & & & \\
\hline Traumatic Synovitis .. & $\cdots$ & $\ldots$ & $\ldots$ & $\begin{array}{l}\text { Serum } \\
\text { Synovium }\end{array}$ & $\begin{array}{l}6 \\
6\end{array}$ & $\begin{array}{l}7 \cdot 67 \\
4 \cdot 76\end{array}$ & $\begin{array}{l}50 \cdot 7 \\
58 \cdot 4\end{array}$ & $\begin{array}{l}4 \cdot 2 \\
3 \cdot 6\end{array}$ & $\begin{array}{r}11 \cdot 2 \\
6 \cdot 3\end{array}$ & $\begin{array}{l}11 \cdot 2 \\
10 \cdot 8\end{array}$ & $\begin{array}{l}22 \cdot 6 \\
21 \cdot 0\end{array}$ \\
\hline Rheumatoid Arthritis & . & $\ldots$ & $\cdots$ & $\begin{array}{l}\text { Serum } \\
\text { Synovium }\end{array}$ & $\begin{array}{l}31 \\
38\end{array}$ & $\begin{array}{l}7 \cdot 03 \\
4 \cdot 9\end{array}$ & $\begin{array}{l}43 \cdot 1 \\
43 \cdot 7\end{array}$ & $\begin{array}{l}5 \cdot 1 \\
4 \cdot 5\end{array}$ & $\begin{array}{r}13 \cdot 1 \\
8 \cdot 8\end{array}$ & $\begin{array}{l}13 \cdot 7 \\
11 \cdot 2\end{array}$ & $\begin{array}{l}25 \\
31 \cdot 2\end{array}$ \\
\hline Rheumatic Fever & . & . & $\cdots$ & $\begin{array}{l}\text { Serum } \\
\text { Synovium }\end{array}$ & $\begin{array}{l}2 \\
3\end{array}$ & $\begin{array}{l}7 \cdot 47 \\
4 \cdot 05\end{array}$ & $\begin{array}{l}42 \cdot 7 \\
41 \cdot 2\end{array}$ & $\begin{array}{l}4 \cdot 6 \\
4 \cdot 9\end{array}$ & $\begin{array}{r}14 \cdot 9 \\
9 \cdot 6\end{array}$ & $\begin{array}{l}17 \cdot 1 \\
19 \cdot 5\end{array}$ & $\begin{array}{l}20 \cdot 7 \\
24 \cdot 2\end{array}$ \\
\hline \multicolumn{2}{|c|}{ Myeloma and Osteo-arthritis } & . & . & $\begin{array}{l}\text { Serum } \\
\text { Synovium }\end{array}$ & $\begin{array}{l}1 \\
2\end{array}$ & $\begin{array}{l}7 \cdot 8 \\
3 \cdot 43\end{array}$ & $\begin{array}{l}44 \cdot 4 \\
58 \cdot 1\end{array}$ & $\begin{array}{l}3 \cdot 9 \\
3 \cdot 3\end{array}$ & $\begin{array}{r}11 \cdot 3 \\
4 \cdot 3\end{array}$ & $\begin{array}{l}14 \cdot 1 \\
10 \cdot 3\end{array}$ & $\begin{array}{l}26 \cdot 2 \\
23 \cdot 8\end{array}$ \\
\hline Sarcoidosis $\quad \ldots$ & $\cdots$ & . & $\cdots$ & $\begin{array}{l}\text { Serum } \\
\text { Synovium }\end{array}$ & $\begin{array}{l}1 \\
1\end{array}$ & $\begin{array}{l}8 \cdot 55 \\
5 \cdot 5\end{array}$ & $\begin{array}{l}34 \cdot 5 \\
41 \cdot 1\end{array}$ & $\begin{array}{l}1 \cdot 8 \\
1 \cdot 8\end{array}$ & $\begin{array}{l}11 \cdot 1 \\
10 \cdot 4\end{array}$ & $\begin{array}{l}15 \cdot 3 \\
10 \cdot 9\end{array}$ & $\begin{array}{l}37 \cdot 4 \\
35 \cdot 8\end{array}$ \\
\hline Ankylosing Spondylitis & $\cdots$ & $\cdots$ & $\cdots$ & $\begin{array}{l}\text { Serum } \\
\text { Synovium }\end{array}$ & $\begin{array}{l}1 \\
l\end{array}$ & $\begin{array}{l}8 \cdot 85 \\
7 \cdot 6\end{array}$ & $\begin{array}{l}34 \cdot 8 \\
28 \cdot 2\end{array}$ & $\begin{array}{l}4 \cdot 9 \\
3 \cdot 9\end{array}$ & $\begin{array}{r}12 \cdot 0 \\
7 \cdot 0\end{array}$ & $\begin{array}{l}9 \cdot 7 \\
8 \cdot 6\end{array}$ & $\begin{array}{l}38 \cdot 5 \\
52 \cdot 6\end{array}$ \\
\hline
\end{tabular}

fraction in this or any other disease studied, with the exception of ankylosing spondylitis. It is highly improbable that the rheumatoid synovium has a particular permeability to gamma globulin, or that the gamma globulins in this condition have a small molecular weight or other property leading to increased synovial penetrating power. The answer must be that some of this gamma globulin has been produced locally in the synovium and the evidence for this is as follows:

(1) No fewer than thirteen of the 38 rheumatoid arthritic synovial fluids contained an equal or greater absolute concentration of gamma globulin as measured by this somewhat crude technique than did the corresponding sera.

(2) In other diseases, such as sarcoidosis and myelomatosis, the high serum gamma globulin was not matched by such high levels in the synovial fluid, though ankylosing spondylitis behaved similarly to rheumatoid arthritis in this respect.

(3) The latex-agglutination, which can be regarded as an index of one gamma globulin, was occasionally more strongly positive in the synovial fluid than in the serum.

(4) The synovial membrane in rheumatoid arthritis is heavily infiltrated with lymphocytes and plasma cells and there is now a good deal of evidence (summarized in the review of Gitlin, Gross, and Janeway, 1959) that these cells can produce gamma globulin.
(5) The cellular infiltration seems heaviest in $\stackrel{\partial}{\supset}$ those cases with the highest synovial fluid $\vec{\oplus}$ gamma globulin levels.

A comparison of the serum and synovial fluid protein patterns when each protein fraction is expressed as a percentage of the total serum or $\bar{\partial}$ synovial fluid protein is shown in Table $V$. The patterns for serum and synovial fluid are surprisingly $\stackrel{\mathbb{Q}}{\complement}$ similar and in this respect the results closely resemble $\overrightarrow{\vec{O}}$ those of Decker and others (1959). These authors $\frac{3}{3}$ also examined serum and synovial fluid obtained after death from ten subjects with no rheumatic disease, and they found a much greater proportion of albumin and relatively less globulin in the synovial fluid than in the serum. Because of the $\frac{5}{3}$ very low serum albumin levels, which were pre- $\frac{3}{6}$ sumably due to the various diseases causing death, $\stackrel{\circ}{\%}$ however, these cannot be accepted as normal serum or synovial fluid patterns. The latter do resemble 음 findings in normal cows' synovial fluid (Ropes and $D$ Bauer, 1953), so that it seems likely that normal synovium is relatively impermeable to the larger of globulin molecules.

In arthritic subjects the present results agree $\mathcal{N}$ closely with those of Decker and others (1959) $\mathrm{N}$ and Nettelbladt and Sundblad (1959). When the various protein fractions are expressed as a per- 0 centage of the total proteins, the patterns in serum $\Phi$ and synovial fluid are remarkably similar, but the ? following differences occur consistently:

There were slightly smaller proportions of alpha $a_{2}$ and beta globulins in synovial fluid than in serum, regardless $\stackrel{\odot}{\mathscr{Q}}$ of the disease process; this is not unexpected in view $\stackrel{\mathbb{Q}}{\mathscr{Q}}$ of the large molecular weight of these proteins. 
There was a greater proportion of albumin in the synovial fluid in osteo-arthritis and traumatic synovitis, but very similar proportions were present in the synovial fluid and serum in rheumatoid arthritis.

Finally, a greater proportion of gamma globulin was present in the synovial fluid in rheumatoid arthritis; this has already been discussed.

The synovial fluid protein pattern represents a balance between proteins entering the joint, mainly from the plasma, and proteins leaving by way of the lymphatics. Clearly, the most important factor influencing the entry of protein is the permeability of the synovial membrane, and this is normally freely permeable to albumin but less so to the larger globulin molecules. Owing to increased vascularity, the arthritic synovial membrane becomes much more permeable and, judging from the entry of myeloma globulin into an osteo-arthritic joint, surprisingly large molecules can traverse the inflamed membrane.

With regard to the reabsorption of protein from the joint, Ropes and Bauer (1933) have shown that, while small molecules can leave normal joints quite rapidly, certain large globulin molecules escape with difficulty. Also Rodnan and MacLachlan (1960) have shown that the rates of re-absorption of radio-iodine-labelled albumin and gamma globulin from normal joints are very similar. In rheumatoid subjects, however, radio-iodine-labelled albumin is absorbed more rapidly from arthritic than from clinically normal joints (Ahlström and others, 1956), but there is no information on the absorption of globulins from diseased joints. From the available data it seems likely that, while albumin enters the inflamed joint more readily, it also escapes more rapidly, and that the various globulin fractions behave similarly but with slower turnover rates. This slower turnover rate for the globulin fractions might well compensate for the greater permeability of the synovium to albumin and might account for the similarity between the serum and synovial fluid protein patterns in certain arthritic diseases.

\section{Summary}

The protein fractions in serum and synovial fluids collected simultaneously from patients with various joint diseases have been estimated electrophoretically.

The general electrophoretic patterns were similar in serum and synovial fluid in most diseases. However, the synovial fluid gamma globulin and the synovial fluid/serum gamma globulin ratio were both greater in rheumatoid arthritis and ankylosing spondylitis than in any of the other diseases studied.
Although the synovial fluid proteins are mostly derived from the plasma proteins, evidence is presented that some of the gamma globulin in the synovial fluid of rheumatoid arthritic patients is formed in the synovial membrane, probably by infiltrating lymphocytes and plasma cells.

We are grateful to the various physicians at Charing Cross, Hammersmith, and St. Bartholomew's Hospitals for permission to study their cases, and to Dr. J. Swale for advice and help with laboratory facilities. We also acknowledge the facilities kindly provided by the Charing Cross Research Committee.

\section{REFERENCES}

Ahlström, S., Gedda, P. O., and Hedberg, H. (1956). Acta rheum. scand., 2, 129.

Bauer, W., Short, C. L., and Bennett, G. A. (1933). J. exp. Med., 57, 419.

Decker, B., McKenzie, B. F., McGuckin, W. F., and Slocumb, C. H. (1959). Arthr. and Rheum., 2, 162.

Gitlin, D., Gross, P. A. M., and Janeway, C. A. (1959). New Engl. J. Med., 260, 21.

Jencks, W. P., Smith, E. R. B., and Durrum, E. L. (1956). Amer. J. Med., 21, 387.

Nettelbladt, E., and Sundblad, L. (1959). Arthr. and Rheum., 2, 144.

- - (1961). Ibid., 4, 161.

Rodnan, G. P., and MacLachlan, M. J. (1960). Ibid., 3,152 .

Ropes, M. W., and Bauer, W. (1953). "Synovial Fluid Changes in Joint Disease." Harvard University Press, Cambridge, Mass.

-, Bennett, G. A., Cobb, S., Jacox, R., and Jessar, R. A. (1959). Ann. rheum. Dis., 18, 49.

Schmid, K., and MacNair, M. B. (1956). J. clin. Invest., $35,814$.

Singer, J. M., and Plotz, C. M. (1958). Arthr. and Rheum., 1, 142.

Protéines du sérum et du liquide synovial dans l'arthrite RÉSUMÉ

On détérmina électrophorétiquement les fractions des protéines dans le sérum et le liquide synovial, prélevés simultanéament sur des sujets atteints de différentes maladies articulaires.

En général, les tableaux électrophorétiques furent similaires dans le sérum et dans le liquide synovial dans la plupart des maladies. Toutefois, le taux de la globuline gamma dans le liquide synovial et le rapport entre celui dans le liquide synovial et celui dans le sérum furent supérieurs dans l'arthrite rhumatismale et dans la spondylarthrite ankylosante que dans toute autre maladie étudiée ici.

Bien que les protéines du liquide synovial dérivent surtout des protéines du plasma, on présente ici des faits indiquant qu'en partie la globuline gamma du liquide synovial des malades atteints d'arthrite rheumatismale est formée dans la membrane synoviale, probablement par des lymphocytes d'infiltration et des plasmocytes. 
Proteinas del suero y del líquido sinovial en la artritis SUMARIo

Se determinaron electroforéticamente las fracciones proteínicas en el suero y el líquido sinovial, recogidos simultáneamente en sujetos con diferentes enfermedades articulares.

En la mayoria de las enfermedades los cuadros electroforéticos generales fueron similares en el suero y en el líquido sinovial. Sin embargo, las cifras de la globu- lina gamma del líquido sinovial y la relación entre ésta y la del suero fueron superiores en la artritis reumatoide y en la espondilartritis anquilosante que en las demás enfermedades estudiadas.

Aunque las proteinas del líquido sinovial derivan sobre todo de las proteinas del plasma, se presentan aquí datos indicando que una parte de la globulina gamma del líquido sinovial de enfermos con artritis reumatoide es formada en la membrana sinovial, probablemente por los linfocitos de infiltración y por los plasmocitos. 